\title{
PEMANFAATAN INTERNET SEBAGAI SUMBER BELAJAR BAGI MAHASISWA FAKULTAS EKONOMI UNIVERSITAS ISLAM NEGERI MULANA MALIK IBRAHIM MALANG
}

\author{
Khairul Mujahidi \\ Email : khairul.mujahidi@yahoo.co.id \\ Zuraidah \\ Email : ida.zuraidah94@yahoo.co.id
}

\begin{abstract}
Abstrak : Sumber belajar saat ini selain dari buku di perpustakaan yang tersedia di kampus, sekarang ini berkembang teknologi internet yang memberikan kemudahan dan keleluasaan dalam menggali ilmu pengetahuan. Melalui internet mahasiswa dapat mengakses berbagai literatur dan referensi ilmu pengetahuan yang dibutuhkan dengan cepat, sehingga dapat mempermudah proses belajar. Penelitian ini ingin mengetahui sejauh mana mahasiswa Fakultas Ekonomi Jurusan Manajmen, Akuntansi dan D3 Perbankan Universitas Maulana Malik Ibrahim Malang telah memanfaatkan teknologi internet sebagai sumber belajar yang mendukung proses belajarnya di bangku kuliah. Dengan menggunakan desain penelitian survey, yang dipakai untuk tujuan eksplorasi. Populasi dan wilayah generalisasi penelitian ini adalah 100 mahasiswa Fakultas Ekonomi UIN Maliki Malang jurusan Manajemen, Akuntansi dan D3 Perbankan yang meliputi mahasiswa angkatan 2011 dan 2012. Hasi penelitian ditemukan, masih banyak mahasiswa mencetak dan atau men-download hasil penelusuran itu untuk dibawa pulang. Informasi yang berupa artikel pada e-journal serta e-book tampaknya kurang begitu sering dicari karena sebagian responden membutuhkan dana tambahan untuk mengaksesnya. Namun demikian penguasaan teknologi internet masih menjadi hal yang sangat mempengaruhi pemaksimalannya dalam fungsi internet sebagai sumber informasi bagi para responden.
\end{abstract}

Kata kunci : internet, men-download, ilmu pengetahuan.

\section{PENDAHULUAN}

Seiring dengan perubahan paradigma pembelajaran, maka keberhasilan kegiatan belajar mengajar di perguruan tinggi tidak hanya ditentukan oleh faktor

Khairul Mujahidi, adalah Mahasiswa Fakultas Ekonomi UIN Maulana Malik Ibrahim Malang

Zuraidah, adalah Dosen Fakultas Ekonomi UIN Maulana Malik Ibrahim Malang 
pengajar/dosen, melainkan sangat dipengaruhi oleh keaktifan mahasiswa. Kurikulum baru tahun 2009 mempertegas bahwa proses pembelajaran harus berpusat pada peserta belajar, pengajar bukan sebagai satu-satunya sumber belajar atau sumber informasi, melainkan berperan sebagai fasilitator, dinamisator, dan motivator dalam pembelajaran.

Selain sumber belajar berupa perpustakaan yang tersedia di kampus, sekarang ini berkembang teknologi internet yang memberikan kemudahan dan keleluasaan dalam menggali ilmu pengetahuan. Melalui internet mahasiswa dapat mengakses berbagai literatur dan referensi ilmu pengetahuan yang dibutuhkan dengan cepat, sehingga dapat mempermudah proses belajar.

Penelitian ini ingin mengetahui sejauh mana mahasiswa Fakultas Ekonomi Jurusan Manajmen, Akuntansi dan D3 Perbankan Universitas Maulana Malik Ibrahim Malang telah memanfaatkan teknologi internet sebagai sumber belajar yang mendukung proses belajarnya di bangku kuliah.

Berdasarkan latar belakang masalah di atas, dapat diidentifikasi permasalahan yang berkaitan dengan pemanfaatan sumber belajar, antara lain : optimalisasi pemanfaatan perpustakaan sebagai sumber belajar, pemenuhan koleksi buku-buku yang tersedia di perpustakaan, pemanfaatan internet sebagai sumber belajar, serta pemanfaatan sumber daya lingkungan sebagai sumber belajar.

Meskipun banyak permasalahan yang berkaitan dengan pemanfaatan sumber belajar dalam proses pembelajaran, namun dalam penelitian ini hanya membatasi pada masalah pemanfaatan internet sebagai sumber belajar oleh mahasiswa Fakultas Ekonomi Jurusan Manajemen, Akuntansi dan D3 Perbankan Universitas Islam Negeri Maulana Malik Ibrahim Malang.

Untuk memperjelas permasalahan yang akan diteliti, maka masalah tersebut dirumuskan sebagai berikut :

1. Apakah mahasiswa Fakultas Ekonomi Jurusan Manajemen, Akuntansi dan D3 Perbankan telah memanfaatkan internet sebagai sumber belajar?

2. Alasan apa yang memotivasi mahasiswa Fakultas Ekonomi Jurusan Manajemen, Akuntansi dan D3 Perbankan memanfaatkan internet sebagai sumber belajar?

3. Faktor apa sajakah yang mendukung dan menghambat mahasiswa Fakultas Ekonomi Jurusan Manajemen, Akuntansi dan D3 Perbankan untuk memanfaatkan internet sebagai sumber belajar?

\section{TINJAUAN PUSTAKA}

\section{Pengertian Internet}

Pengertian Internet adalah kependekan dari inter-network. Secara harfiah mengandung pengertian sebagai jaringan komputer yang menghubungkan beberapa rangkaian (www.wikipedia.com). Jaringan internet juga didefinisikan sebagai jaringan komputer yang mampu menghubungkan komputer di seluruh dunia sehingga berbagai jenis dan bentuk informasi dapat dikomunikasikan antar belahan dunia secara instan dan global (www.jurnal-kopertis4.org). Selain kedua pengertian di atas, internet juga disebut sebagai sekumpulan jaringan komputer yang menghubungkan situs akademik, pemerintahan, komersial, organisasi, 
maupun perorangan. Internet menyediakan akses untuk layanan telekomunikasi dari sumber daya informasi untuk jutaan pemakainya yang tersebar di seluruh dunia. Layanan internet meliputi komunikasi langsung (e-mail, chat), diskusi (usenet news, milis, bulletin board), sumber daya informasi yang terdistribusi (World Wide Web, Ghoper), remote login dan lalu lintas file (Telnet, FTP), serta berbagai layanan lainnya (www.andhika.com).

Sejalan dengan perkembangan internet, telah banyak aktivitas yang dilakukan dengan memanfaatkan jaringan internet, seperti e-Commerce, e-Banking, e-Government, e-Learning dan lainnya. Salah satu aktivitas yang berkaitan dengan proses pembelajaran adalah e-Learning. E-Learning adalah wujud penerapan teknologi informasi di bidang pendidikan dalam bentuk sekolah maya. E-Learning merupakan usaha untuk membuat sebuah transformasi proses belajar mengajar di sekolah dalam bentuk digital yang dijembatani oleh teknologi internet.

\section{Internet dalam Kegiatan Belajar}

Kekayaan informasi yang sekarang tersedia di internet telah lebih mencapai harapan dan bahkan imajinasi para penemu sistemnya. Melalui internet dapat diakses sumber-sumber informasi tanpa batas dan aktual dengan sangat cepat. Adanya internet memungkinkan seseorang di Indonesia untuk mengakses perpustakaan di Amerika Serikat dalam bentuk Digital Library. Sudah banyak pengalaman tentang kemanfaatan internet dalam penelitian dan penyelesaian tugas akhir mahasiswa. Tukar menukar informasi atau tanya jawab dengan pakar dapat juga dilakukan melalui internet. Tanpa teknologi internet banyak tugas akhir dan thesis atau bahkan desertasi yang mungkin membutuhkan waktu lebih banyak untuk menyelesaikannya (www.jurnal-kopertis4.org).

Sementara itu mahasiswa juga dapat menggunakan internet untuk belajar sendiri secara cepat, sehingga akan meningkatkan dan memeperluas pengetahuan, belajar berinteraksi, dan mengembangkan kemampuan dalam bidang penelitian (www.pendidikan.net).

Dalam www.jurnal-kopertis4.org disebutkan beberapa manfaat internet bagi pendidikan di Indonesia, yaitu : akses ke perpustakaan, akses ke pakar, perkuliahan online, layanan informasi akademik, menyediakan fasilitas mesin pencari data, menyediakan fasilitas diskusi, dan fasilitas kerjasama.

\section{Pengertian Sumber Belajar}

Menurut Association for Educational Communications and Technology sumber pembelajaran adalah segala sesuatu atau daya yang dapat dimanfaatkan oleh guru, baik secara terpisah maupun dalam bentuk gabungan, untuk kepentingan belajar mengajar dengan tujuan meningkatkan efektivitas dan efisiensi tujuan pembelajaran.

Sumber pembelajaran dapat dikelompokan menjadi dua bagian, yaitu :

1) Sumber pembelajaran yang sengaja direncanakan (learning resources by design), yakni semua sumber yang secara khusus telah dikembangkan sebagai komponen sistem instruksional untuk memberikan fasilitas belajar yang terarah dan bersifat formal; dan

2) Sumber pembelajaran yang karena dimanfaatkan (learning resources by utilization), yakni sumber belajar yang tidak secara khusus didisain untuk 
keperluan pembelajaran namun dapat ditemukan, diaplikasikan, dan dimanfaatkan untuk keperluan belajar-salah satunya adalah media massa.

\section{METODE}

Penelitian ini menggunakan desain penelitian survey, yang dipakai untuk tujuan eksplorasi. Penelitian ini bertujuan untuk menggali informasi tentang pemanfaatan internet sebagai sumber belajar oleh mahasiswa program studi Manajemen, Akuntansi dan D3 Perbankan UIN Maliki Malang. Populasi dan wilayah generalisasi penelitian ini adalah 100 mahasiswa Fakultas Ekonomi UIN Maliki Malang jurusan Manajemen, Akuntansi dan D3 Perbankan yang meliputi mahasiswa angkatan 2011 dan 2012. Sampel penelitian diambil secara proporsional random sampling. Teknik pengumpulan data yang digunakan dalam penelitian ini adalah kuesioner. Data yang terkumpul akan dianalisis secara deskriptif dengan tabulasi dan persentase.

\section{PEMBAHASAN}

\section{Karakteristik Responden}

Yang mana telah disebutkan pada bab metode penelitian, bahwa studi ini bersifat deskriptif kuantitatif dengan menggunakan tabulasi kuesioner sebagai bagian dari proses analisis data. Berdasarkan teknik pemilihan sampel yang digunakan, maka diperoleh sebanyak 100 orang mahasiswa Fakultas Ekonomi UIN Maliki Malang jurusan Manajemen, Akuntansi dan D3 Perbankan sebagai responden. Mengingat proses penyebaran kuesioner yang bersifat accidental maka diperoleh responden dengan latar belakang jurusan yang berbeda. Hasil tabulasi kuesioner yang dilakukan diperoleh gambaran bahwa mahasiswa yang terbanyak menjadi responden adalah mahasiswa dari Jurusan Manajemen sebanyak 44 orang (68\%) dan kemudian disusul oleh mahasiswa Jurusan Akuntansi dan D3 Perbankan dengan jumlah beragam.

\section{Pengalaman Menggunakan Internet}

Berdasarkan seleksi kuesioner yang kembali diketahui bahwa tidak semua responden mampu menggunkan komputer dan yang sebagaimana dikriteriakan kajian itu bahwa yang menjadi responden adalah mahasiswa yang mampu mengoperasikan komputer. Namun demikian berdasarkan tabulasi jawaban responden diketahui bahwa kemampuan para responden mengoperasikan komputer dominan diperoleh sebelum menjadi mahasiswa Fakultas Ekonomi. Tabulasi kuesioner yang dilakukan menunjukan hasil bahwa dari 100 orang responden hanya sekitar 39 (48\%) responden mampu menggunakan internet setelah mereka menjadi mahasiswa Fakultas Ekonomi UIN Maliki Malang dan bagaian terbesar yakni sebanyak 41 orang atau sekitar $62 \%$ telah mengetahui sebelum menjadi mahasiswa, padahal semua responden sebelum menjadi mahasiswa telah mengenal komputer. 
Fenomena yang terjadi di kalangan mahasiswa Fakultas Ekonomi, jelas menunjukan mereka telah menjadikan internet sebagai salah satu sumberdaya media informasi guna memenuhi kebutuhan informasi sebagai konsekuen dari studi yang mereka lakukan.

\section{Penggunaan Internet}

Pengetahuan menggunakan internet yang dimiliki oleh sebagaian responden menunjukan bahwa sebagaian besar responden belum menggunakan internet dalam jangka waktu yang cukup lama. Hal ini terbukti dari 100 orang responden, hanya ada sepuluh orang yang telah menggunakan internet selama lebih dari 8 tahun sedangkan pengalaman selebihnya hanya berkisar satu sampai dengan 4 tahun.

Pengalaman menggunakan internet yang bervariasi tersebut tentunya sangat dipengaruhi oleh beragam latar belakang, namun satu hal yang pasti bahwa aktivitas untuk menggunakan internet dirasakan oleh semua responden muncul dan bertambah setelah mereka menjadi mahasiswa Fakultas Ekonomi. Gambarnya secara umum mengenai lama waktu yang telah digunakan oleh responden dalam menggunakan internet dapat dilihat pada table 1 berikut.

Tabel 1: Masa Penggunaan Internet yang Dimiliki oleh Responden

\begin{tabular}{|c|c|c|}
\hline Masa Penggunaan Internet & Frekuensi & Persentase \\
\hline $1-4$ bulan & 27 & 28.0 \\
\hline $5-8$ bulan & 12 & 12.0 \\
\hline $9-12$ bulan & 25 & 18.0 \\
\hline $1-4$ tahun & 32 & 34.0 \\
\hline $5-8$ tahun & 2 & 4.0 \\
\hline Lebih dari 8 tahun & 2 & 4.0 \\
\hline Total & 100 & 100.0 \\
\hline
\end{tabular}

Sumber data : diolah, 2012

Variasi waktu yang berbeda mengenai masa penggunaan intenet yang terjadi di kalangan mahasiswa Fakultas Ekonomi UIN Maliki Malang juga dipengaruhi oleh latar belakang domisili responden yang tidak semuanya dari kota dimana terdapat lembaga yang menyediakan fasilitas internet. Hal ini dapat dilihat dari alamat responden berada di desa yang dipastikan bahwa belum terdapat fasilitas layanan internet.

\section{Pengenalan Internet}

Kemampuan mahasiswa Fakultas Ekonomi UIN Maliki Malang dalam mengenal dan menggunakan internet ternyata juga tidak sama. Proses belajar untuk mengenal dan menggunakan internet yang ada di kalangan mahasiswa Fakultas Ekonomi berdasarkan tabulasi data yang digunakan lebih didominasi atas bantuan teman. Uraian yang lebih jelas lagi mengenai bagaimana proses mahasiswa Fakultas Ekonomi UIN Maliki Malang mengenal dan menggunakan internet dapat dilihat pada table 2 berikut. 
Tabel 2: Sumber Pengenalan Internet para Responden

\begin{tabular}{|c|c|c|}
\hline Sunber Pembelajaran Penggunaan Internet & Frekuensi & Persentase \\
\hline Tidak menjawab & 1 & 2.0 \\
\hline Melalui kursus & 3 & 6.0 \\
\hline Bantuan teman & 59 & 78.0 \\
\hline Mencoba sendiri & 37 & 14.0 \\
\hline Total & 100 & 100.0 \\
\hline
\end{tabular}

Sumber data : diolah, 2012

Dari table diatas banyak hal yang bisa diketahui, diantaranya bahwa sebagian responden lebih menjadikan teman sebagai sumber atau pihak yang membantu mengajari atau memperkenalkan responden pada internet, dan ini diakui oleh 59 orang responden atau sekitar $78 \%$ dari total keseluruhan responden. Hal lain yang juga bisa diketahui adalah bahwa hanya ada tiga orang responden yang mengatakan bahwa mereka mengenal penggunaan internet dengan mengikuti kursus khusus. Ini artinya media kursus belum menjadi media yang efektif dalam pentransferan pengetahuan internet.

Ada hal yang menarik dari table di atas yaitu bahwa tidak seorangpun mahasiswa menjawab bahwa pengetahuan yang mereka miliki dalam menggunakan internet diperoleh atas bantuan pustakawan khususnya pustakawan yang ada di lingkungan UIN Maliki Malang. Hal yang demikian ini sebetulnya merupakan kondisi yang wajar sebab di lingkungan Fakultas Ekonomi UIN Maliki Malang sendiri termasuk di perpustakaan tidak tersedia pusat layanan digital yang menggunakan internet sebagai sarana untuk mengaksesnya. Ini artinya bahwa ketiadaan fasilitas fisik telah menjadikan pustakawan tidak begitu berperan dalam proses pembelajaran pengguanaan internet yang terjadi di kalangan mahasiswa Fakultas Ekonomi UIN Maliki Malang. Penjelasan lain juga bisa digunakan untuk menjelaskan mengapa pustakawan tidak menjadi pihak yang terlibat dalam proses pembelajaran internet yang dilakukan oleh mahasiswa Fakultas Ekonomi UIN Maliki Malang adalah dikarenakan sebagaian besar mereka yaitu sekitar 39-an orang dari 100 responden mengetahui internet sebelum mereka menjadi mahasiswa. Selain itu umunya mahasiswa telah mengenal internet sebelum mereka kuliah di UIN Maliki Malang, dan bagi yang mengetahui internet sesudah menjadi mahasiswa UIN Maliki Malang-pun tetap menjadikan teman sebagai orang yang dapat membantu mengenalkan internet, dan hanya tujuh orang yang belajar secara otodidak. Dengan demikian secara keseluruhan dapat dikatakan bahwa pengetahuan mahasiswa Fakultas Ekonomi UIN Maliki Malang dalam menggunakan internet lebih didominasi atas bantuan teman.

\section{Motifasi Menggunakan Internet}

Tuntutan perkuliahan yang mendorong mahasiswa untuk menggunakan internet tentunya merupakan sebuah hal yang wajar. Akan tetapi data yang diperoleh dan responden menunjukan kenyataan bahwa rasa ingin tahu menjadi motivasi utama yang mendorong mereka untuk menggunakan internet. Analisis terhadap angket yang disebarkan menunjukkan bahwa sebanyak 57 orang responden atau 54\% mengatakan bahwa motivasi mereka dengan menggunakan 
internet hanya didasarkan pada upaya memenuhi rasa ingin tahu. Kemudahan akses informasi yang diperoleh dengan menggunakan internet diungkapkan oleh 12 orang responden atau sekitar $24 \%$ dan yang menjadikan motivasi penggunaan internet untuk mendukung perkuliahan sebanyak 31 orang (22\%). Untuk lebih jelas data mengenai motivasi mahasiswa Fakultas Ekonomi UIN Maliki Malang menggunakan internet dapat dilihat pada table berikut

Table 3 : Motivasi Mahasiswa Fakultas Ekonomi UIN Maliki Malang Menggunakan Internet

\begin{tabular}{|l|c|r|}
\hline \multicolumn{1}{|c|}{ Motivasi Menggunakan Internet } & Frekuensi & \multicolumn{2}{c|}{ Persentase } \\
\hline Kemudahan akses dan komunikasi & 12 & 24.0 \\
\hline Rasa ingin tahu & 57 & 54.0 \\
\hline Tuntutan studi Total & 31 & 22.0 \\
\hline \multicolumn{2}{|c|}{ To0 } & $\mathbf{1 0 0 . 0}$ \\
\hline
\end{tabular}

Sumber data : diolah 2012

Motivasi menggunakan internet, yang ditunjukan oleh mahasiswa Fakultas Ekonomi UIN Maliki Malang berbeda antara yang satu dengan yang lainnya, hal tersebut dapat dipicu oleh berbagai keperluan dan kebutuhan akan pengguanaan internet itu sendiri yang juga cenderung berbeda

Upaya memulai kebutuhan rasa ingin tahu yang merupakan motivasi dominan yang di tunjukan oleh mahasiswa Fakultas Ekonomi UIN Maliki Malang pada giliranya juga menunjukan bahwa sebagian besar mahasiswa Fakultas Ekonomi UIN Maliki Malang menyadari arti penting informasi. Tidak hanya itu kemudahan informasi yang disediakan oleh internet juga merupakan sebuah sarana efektif untuk memenuhi rasa keingintahuan akan informasi. Hal lain yang juga bisa ditafsirkan dari motivasi yang demikian bahwa mahasiswa Fakultas Ekonomi UIN Maliki Malang menggunakan internet tidak hanya di saat akan mengerjakan tugastugas perkuliahan saja, mereka juga tetap akan menggunakan internet atas kemauan sendiri untuk mencari bahan kuliah.

Namun amat sangat disayangkan bahwa motivasi yang sedemikian itu ternyata tidak serta merta dibarengi dengan penyediaan sarana oleh pihak pengelola Fakultas Ekonomi UIN Maliki Malang. Kondisi yang demikian itu sama artinya bahwa pengelola program tidak memperhatikan kebutuhan mahasiswa yang mengikuti perkuliahan pada Fakultas Ekonomi UIN Maliki Malang.

\section{Tujuan dan Manfaat Menggunakan Internet} Tujuan

Sebagaimana disebutkan di bagian awal bahwa hampir sebagian besar mahasiswa Fakultas Ekonomi UIN Maliki Malang merasa bahwa tuntutan untuk menggunakan internet semakin besar seiring dengan perkuliahan yang mereka ikuti. Ini menunjukkan bahwa alas an untuk mempelancar perkuliahan jelas merupakan sebuah alas an yang masuk akal yang dianut sebagian besar mahasiswa Fakultas Ekonomi UIN Maliki Malang dalam menggunakan internet. Analisis terhadap data yang diperoleh menunjukkan kenyataan bahwa mayoritas tujuan mahasiswa Fakultas Ekonomi UIN Maliki Malang menggunakan internet adalah untuk memperoleh informasi yang cenderung mendukung perkuliahan mereka. Tabulasi 
kuisioner menunjukkan bahwa ada banyak 65 (70\%) orang responden menggunakan internet dengan tujuan untuk mencari informasi ilmiah, sebanyak 17 orang (14\%) menggunakan internet untuk membaca berita, 16 orang (12\%) menggunakan intenet dengan tujuan untuk mengecek dan mengirim e-mail dan selebihnya. 2 orang (4\%) bertujuan untuk mencari informasi non ilmiah. Secara umum gambaran tentang tujuan utama para mahasiswa Fakultas Ekonomi UIN Maliki Malang menggunakan internet dapat dilihat pada tabel berikut:

Tabel 4: Tujuan Responden Menggunakan Internet

\begin{tabular}{|l|c|r|}
\hline \multicolumn{1}{|c|}{ Tujuan Menggunakan Internet } & Frekuensi & \multicolumn{1}{c|}{ Persentase } \\
\hline Mencari informasi & 65 & 70.0 \\
\hline Mencari berita & 17 & 14.0 \\
\hline Mencari informasi non ilmiah & 2 & 4.0 \\
\hline E-mail Total & 16 & 12.0 \\
\hline \multicolumn{2}{|c|}{ Ton } & $\mathbf{1 0 0 . 0}$ \\
\hline
\end{tabular}

Sumber data : diolah 2012

Informasi ilmiah yang biasa dicari oleh mahasiswa Fakultas Ekonomi UIN Maliki Malang ketika mejelajah di internet adalah artikel-artikel ilmiah yang dimuat dalam jurnal-jurnal elektronik dan sebagainya. Adapun informasi non ilmiah yanh cenderung dikonsumsi oleh mahasiswa Fakultas Ekonomi UIN Maliki Malang berupa informasi popular menyangkut banyak hal mulai dari rubik tentang artis, tokoh-tokoh public astrologi dan sebagainya.

Namun demikian hal yang juga dapat disimpulkan dari table di atas bahwa tidak ada mahasiswa Fakultas Ekonomi UIN Maliki Malang yang tujuan utamanya menggunakan internet hanya untuk Chatting (mengobrol di alam maya) dan Shopping (berbelanja). Ini tentunya merupakan hal yang baik juga bisa menjadi indicator bahwa tidak semua mahasiswa Fakultas Ekonomi UIN Maliki Malang mempu memanfaatkan fasilitas yang ada di internet.

\section{Manfaat}

Tindakan orang melakukan atau menggunakan sesuatu pasti dibarengi dengan adanya harapan untuk memperoleh suatu manfaat dari tindakan yang dilakukan. Aktifitas pemenuhan kebutuhan akan informasi dengan menggunakan internet yang dilakukan oleh mahasiswa Fakultas Ekonomi UIN Maliki Malang juga memiliki tujuan yang berbeda antara satu mahasiswa dengan mahasiswa lainya. Perbedaan manfaat yang diharapkan dari penggunaan internet tersebut tentunya di pengaruhi oleh banyak hal, diantaranya adalah motivasi penggunaan internet itu sendiri. Latar belakang lingkungan social budaya, pendidikan, pekerjaan dan lainya. Berdasarkan jawaban yang diberikan para responden menyangkut pertanyaan tentang tujuan mereka menggunakan internet diperoleh jawaban bahwa sebanyak 43 orang (46\%) menyatakan manfaat penggunaan internet membantu kelancaran studi. Sementara itu terdapat 27 orang $(34,0 \%)$ menyatakan internet bermanfaat untuk memperlancar komunikasi yang mereka lakukan dan selebihnya ada yang menjawab bahwa internet membantu menghilangkan kepenatan atau dengan kata lain internet sebagai sarana hiburan dan ada pula yang menyatakan bahwa internet membantu tugas-tugas di tempat kerja. 
Disamping itu, ada juga beberapa responden tidak memberikan jawaban yang pasti dan hal ini dikenakan mereka merasa bahwa internet yang mereka lakukan tidak secara signifikan diketahui menfaatnya. Namun demikian ada pula keengganan sebagian mereka menjawab, karena semua pilihan yang ada dalam lembaran angket merupakan manfaat yang mereka terima. Perbandingan jawaban diantara yang tidak menjawab karena tidak tahu dengan mereka yang merasa semuanya bermanfaat tidak diperoleh dengan jelas. Untuk lebih jelas jawaban responden menyangkut manfaat penggunaan internet dapat dilihat pada table 5 berikut.

Tabel 5: Manfaat Penggunaan Internet

\begin{tabular}{|l|c|r|}
\hline \multicolumn{1}{|c|}{ Manfaat Menggunakan Internet } & Frekuensi & \multicolumn{2}{c|}{ Persentase } \\
\hline Tidak menjawab & 3 & 2.0 \\
\hline Membantu keperluan studi & 43 & 46.0 \\
\hline Media komunikasi & 27 & 34.0 \\
\hline Membantu keperluan tugas & 11 & 6.0 \\
\hline Hiburan $\quad 16$ & 12.0 \\
\hline \multicolumn{1}{|c|}{ Total } & $\mathbf{5 0}$ & $\mathbf{1 0 0 . 0}$ \\
\hline
\end{tabular}

Sumber data : diolah 2012

Hal lain yang diperoleh dari data di atas adalah motivasi menggunakan internet masih memiliki relevansi dengan manfaat yang diterima oleh mahasiswa Fakultas Ekonomi UIN Maliki Malang. Kondisi yang demikian tentu merupakan hal yang sesuai dengan harapan mahasiswa bahwa dengan internet kebutuhan mereka akan informasi guna memenuhi kebutuhan studi, apakah untuk aktifitas kuliah, kerja maupun liburan dan lainya bisa terpenuhi.

Disamping kondisi tersebut di atas, hal lain yang juga dapat ditafsirkan dari table di atas yakni bahwa secara implisit mahasiswa Fakultas Ekonomi UIN Maliki Malang memposisikan internet sebagai sarana untuk memperoleh informasi dengan tingkatkan yang berbeda. Pernyataan ini juga didukung oleh hasil analisis data yang menunjukkan bahwa sebanyak 33 responden atau sekitar $66 \%$ dari keseluruhan responden memfungsikan informasi dari internet sebagai informasi pelengkap. Hal ini merupakan hal yang wajar dan lumrah sebab dalam beberapa wawancara bebas tak berstruktur diketahui bahwa sebagian besar mahasiswa Fakultas Ekonomi UIN Maliki Malang masih menjadikan buku terutama buku yang dianjurkan oleh dosen sebagai sumber informasi untuk mendukung perkuliahan. Tidak hanya itu, oleh sebagian hanya media cetak seperti Koran, majalah dan jurnal-jurnal ilmiah masih merupakan sumber informasi utama. Untuk lebih jelas lagi mengenai bagaimana mahasiswa Fakultas Ekonomi UIN Maliki Malang merupakan informasi dari internet dalam memenuhi kebutuhan mereka dapat dilihat pada table 6 di bawah ini. 
Tabel 6: Fungsi Informasi dari Internet bagi Para Responden

\begin{tabular}{|c|c|c|}
\hline $\begin{array}{c}\text { Kedudukan Informasi dari } \\
\text { Internet bagi Responden }\end{array}$ & Frekuensi & Persentase \\
\hline Informasi utama & 2 & 4.0 \\
\hline Informasi kedua & 28 & 16.0 \\
\hline Informasi pelengkap & 53 & 66.0 \\
\hline Informasi cadangan & 17 & 14.0 \\
\hline Total & 100 & 100.0 \\
\hline
\end{tabular}

Sumber data : diolah 2012

Berdasarkan table di atas dapat diketahui bahwa posisi buku dan media cetak lainya benar-benar belum bisa digantikan oleh internet. Hal ini tentunya terjadi dikarenakan beberapa factor seperti tingkat pengusaan terhadap semua semua fasilitas yang ada di internet yang dimiliki mahasiswa Fakultas Ekonomi UIN Maliki Malang tidak merata. Disamping itu, factor kemudahan mengakses, latar belakang ekonomi dan tingkat mobilitas mahasiswa kiranya juga merupakan hal yang berpengaruh.

Hal menarik lainya yang juga dapat dilihat dari table di atas bahwa ada sebagian mahasiswa yang hanya menjadikan informasi dan internet sebagian informasi cadangan dan jumlah mahasiswa seperti ini lebih besar dibanding dengan mereka yang menjadikan internet sebagai sumber informasi utama. Ini artinya mereka hanya akan menggunakan informasi yang ada di internet saat sumber informasi lainya tidak bisa memenuhi kebutuhan yang mereka inginkan.

\section{Pola Pemanfaatan Internet Tempat Mengakses}

Pemanfaatan sarana yang menyediakan jasa internet ternyata belum dioptimalkan oleh mahasiswa Fakultas Ekonomi UIN Maliki Malang. Diketahui demikian sebab banyak pusat pelayanan yang menyediakan layanan internet tidak semuanya pernah dimanfaatkan. Berdasarkan tabulasi data yang diperoleh, diketahui bahwa sebagian besar responden atau tepatnya sebanyak 29 orang sering mengakses internet dari warnet, dan 55 orang jarang melakukannya dan ada 16 orang tidak pernah melakukan. Sementara sarana internet yang ada di kampus tampaknya sedikit sekali yang mempergunakan sebab hanya ada 29 orang saja yang sering menggunakan internet di kampus, 55 orang jarang menggunkan dan 16 orang tidak pernah mengakses internet di kampus. Untuk tempat pengakseskan di rumah. Yang sering melakukanya hanya satu orang, 3 orang jarang dan selebihnya tidak pernah. Smentara pengakseskan internet dan hotel tampaknya tidak pernah dilakukan oleh semua responden. Umumnya responden cenderung memfokuskan warung intrnet sebagai sarana pokok sebagai tempat mengakses internet.

Untuk lebih jelas lagi mengenai tempat dimana mahasiswa Fakultas Ekonomi UIN Maliki Malang mengakses internet dapat dilihat pada tabel 7 berikut. 
Tabel 7: Tempat Responden Mengakses Internet

\begin{tabular}{|c|c|c|c|c|c|c|c|c|c|c|}
\hline \multirow{3}{*}{$\begin{array}{c}\text { Tingkat } \\
\text { Pengaksesan }\end{array}$} & \multicolumn{10}{|c|}{ Tempat Mengakses } \\
\hline & \multicolumn{2}{|c|}{ Kampus } & \multicolumn{2}{|c|}{ Warnet } & \multicolumn{2}{|c|}{ Rumah } & \multicolumn{2}{|c|}{ Kafe } & \multicolumn{2}{|c|}{$\begin{array}{c}\text { Rumah } \\
\text { Sewa }\end{array}$} \\
\hline & $\mathrm{F}$ & $\%$ & $\mathrm{~F}$ & $\%$ & $\mathrm{~F}$ & $\%$ & $\mathrm{~F}$ & $\%$ & $\mathrm{~F}$ & $\%$ \\
\hline Sering & 52 & 14.0 & 29 & 38.0 & 1 & 2.0 & - & - & - & - \\
\hline Jarang & 44 & 82.0 & 55 & 50.0 & 33 & 6.0 & 1 & 2.0 & 50 & 50.0 \\
\hline Tidak pernah & 4 & 4.0 & 16 & 12.0 & 66 & 92.0 & 99 & 98.0 & 50 & 50.0 \\
\hline Total & 100 & 100 & 100 & 100 & 100 & 100 & 100 & 100 & 100 & 100 \\
\hline
\end{tabular}

Sumber data : diolah 2012

\section{Perlakuan Terhadap Hasil Penelusuran}

Tingkat relevansi informasi dengan kebutuhan pada gilirannya akan berkaitan dengan tindakan apa yang akan dilakukan responden ketika menemukan informasi tersebut. Pada dasarnya ada tiga macam cara atau tindakan informasi ketika dia sudah menemukan informasi yang dicarinya yaitu men-download (download), mencetaknya, atau hanya membacanya secara langsung di monitor computer. Namun demikian tak jarang ketiga tindakan itu akan dilakukan secara bersamaan sebab tak jarang segala informasi yang akan dicetak harus disimpan terlebih dahulu dan sebelum disimpan harus dipastikan kerelevansian informasi dengan cara membacanya di monitor.

Informasi yang diperoleh dari hasil penelusuran melalui internet adalah berbentuk digital. Ada kalanya informasi yang demikian diperoleh tidak hanya cukup dibaca di monitor computer pada saat melakukan penelusuran, sehingga pengguna merasa perlu membacanya kembali di tempat lain. Untuk hal itu, perlakuan atau tindakan lanjutanyang sering dilakukan pengguna terhadap hasil penelusurannya ialah mencetak dan atau men-download hasil penelusuran itu untuk dibawa pulang.

Tindakan responden dalam merespon informasi yang ditemukannya di internet akan berbeda antara satu dengan yang lainnya. Tabel berikut akan membantu menjelaskan bagaimana perilaku atau tindakan para responden memperlakukan informasi yang mereka cari di internet.

Tabel 8: Perlakuan Responden Terhadap Hasil Penelusuran

\begin{tabular}{|l|c|c|c|c|c|c|c|c|}
\hline \multirow{3}{*}{ Pilihan Jawaban } & \multicolumn{6}{|c|}{ Jawaban Responden } & \multicolumn{3}{c|}{ Total } \\
\cline { 2 - 9 } & \multicolumn{2}{|c|}{ Selalu } & \multicolumn{2}{c|}{ Jarang } & Tidak Pernah & \multicolumn{2}{c|}{} \\
\cline { 2 - 9 } & $\mathrm{F}$ & $\%$ & $\mathrm{~F}$ & $\%$ & $\mathrm{~F}$ & $\%$ & $\mathrm{~N}$ & $\%$ \\
\hline Men-download & 9 & 18.0 & 2 & 4.0 & 39 & 78.0 & 50 & 100.0 \\
\hline Mencetak & 17 & 34.0 & 26 & 52.0 & 7 & 14.0 & 50 & 100.0 \\
\hline Hanya baca di monitor & 26 & 52.0 & 20 & 40.0 & 4 & 8.0 & 50 & 100.0 \\
\hline
\end{tabular}

Sumber data : diolah, 2012

Tindakan terbanyak responden yang selalu membaca terlebih dahulu mengindikasikan bahwa seringkali informasi yang ditentukan tidak menjadi hal yang sangat penting sebab keinginan untuk mengulang atau mengabadikan temuan tersebut tidak bisa dilakukan sementara kemampuan para responden untuk 
menghafal amat mustahil sebab lama waktu yangmereka gunakan di saat online di internet juga sangat minim. Berdasarkan tabel di atas juga masih memungkinkan asumsi lainnya yaitu bahwa ketiga tindakan tersebut bisa saja dilakukan sekaligus oleh responden dalam menyikapi informasi yang ditemukan. Namun yang jelas tabel di atas memperlihatkan bahwa kemampuan penguasaan teknologi internet masih menjadi hal yang sangat mempengaruhi pemaksimalan fungsi internet sebagai sumber informasi bagi para responden.

\section{KESIMPULAN}

\section{Kesimpulan}

Hasil penelitian dan pembahasan dengan tujuan-tujuan pada penelitian ini maka dihasilkan beberapa kesimpulan, antara lain informasi yang diperoleh dari hasil penelusuran melalui internet adalah berbentuk digital. Ada kalanya informasi yang demikian diperoleh tidak hanya cukup dibaca di monitor computer pada saat melakukan penelusuran, sehingga pengguna merasa perlu membacanya kembali di tempat lain. Untuk hal itu, perlakuan atau tindakan lanjutan yang sering dilakukan pengguna terhadap hasil penelusurannya ialah mencetak dan atau men-download hasil penelusuran itu untuk dibawa pulang. informasi yang berupa artikel pada $e$ journal serta $e$-book tampaknya kurang begitu sering dicari. Ketika ditanya alasan mengapa kedua jenis informasi terakhir jarang dicari, sebagian responden menjawab spontan bahwa informasi berupa e-journal dan e-book membutuhkan dana tambahan untuk mengaksesnya. Tingkat pemanfaatan masing-masing titik akses akan tidak sama oleh setiap mahasiswa. Hal ini dikarenakan tingkat kepuasan atau kemudahan pengaksesan masing-masing titik akan dirasakan berbeda oleh setiap mahasiswa. Namun demikian penguasaan teknologi internet masih menjadi hal yang sangat mempengaruhi pemaksimalannya dalam fungsi internet sebagai sumber informasi bagi para responden.

\section{Saran}

Untuk mendukung mahasiswa dalam penggunaan dan pemanfaatan internet sebagai sumber belajar. Meskipun banyak permasalahan yang berkaitan dengan pemanfaatan sumber belajar dalam proses pembelajaran, dan dalam penelitian ini hanya membatasi pada masalah pemanfaatan internet sebagai sumber belajar oleh mahasiswa Fakultas Ekonomi Jurusan Manajemen, Akuntansi dan D3 Perbankan Universitas Islam Negeri Maulana Malik Ibrahim Malang. Untuk itu peneliti nemyarankan agar kedepan khususnya bagi peneliti berikutnya yang berniat mengkaji lebih dalam tentang sikap pengguna internet, pemanfaat lebih lanjut dengan melakukan pengkajian atau penelitian. Sehingga meningkatkan mahasiswa yang benar-benar berwawasan pada bidang studi yang ditekuninya. Bagi peneliti berikut yang berminat meneliti tentang penelitian ini diharapkan menambah atau memfokuskan satu jurusan saja agar lebih mendalam lagi bagaimana pemanfaat penggunaan internet bagi mahasiswa khususnya dalam satu mata kuliah tertentu. Sehingga kita sebagai penelitian dapat memberitahuan pada dosen-dosen pengampuh mata kuliah agar bisa bersama-sama belajar dan membahas matei baru atau penelitian luar negeri yang terbaru. 


\section{DAFTAR PUSTAKA}

Anonim. (2005). Sekilas Perkembangan Internet di Indonesia. www.jurnalkopertis4.org. diambil 24 Februari 2006.

Anonim. (2005). Kamus Istilah Internet.(www.wikipedia.com). diambil 24 Februari 2006.

Arif A Mangkoesapoetro. (2004). Pemanfaatan Media Massa Sebagai Sumber Pembelajaran IPS Di Tingkat Persekolahan. (http://artikel.us/mangkoes6-04-2.html). diambil 27 Februari 2006.

Andhika. (2005). Apa itu Internet? (www.andhika.com). diambil 25 Februari 2006.

Marsell Ruben Payong. (2005). Good Bye Teacher. (www.kompas.com). diambil 24 Februari 2006.

Philip Rechdalle.(2005). Internet dan Pendidikan. (www.pendidikan.net). Diambil 24 Februari 2006. 